\title{
Tingkat Keuntungan Bank di Indonesia setelah Krisis Subprime 2008 di
}

Amerika Serikat

\author{
By: \\ Pandu Adi Cakranegara \\ Email : pandu.cakranegara@president.ac.id
}

Fakultas Bisnis

Universitas Presiden

\begin{abstract}
Subprime Mortgage in America has a wide impact on the world including Indonesia. The researcher examines its relationship with banks in Indonesia. The economic downturn in the United States will have an impact on the global economic downturn. Thus, the Indonesian economy will also be affected. If there is an economic downturn, the financial sector in this case is represented by the banking sector, which will first decrease its value.

The analysis used uses the method of analyzing financial statements. Based on the data from the Audited Financial Report, the banking sector growth and operational performance can be analyzed.

The results found were the linkage of Du Pont's Stock Returns and ROE. High ROE will result in rising stock prices on the market. Nevertheless, market appreciation for each bank is not the same because there are banks that are more appreciated by the market or conversely there are banks that are not appreciated as high as other banks.
\end{abstract}

Keywords: Du Pont ROE, Subprime Mortgage, Financial Statement Analysis, Market Sentiment

\begin{abstract}
Subprime Mortgage di Amerika berdampak luas pada dunia termasuk Indonesia. Peneliti meneliti keterkaitannya dengan Bank di Indonesia. Penurunan ekonomi di Amerika Serikat akan berdampak pada penurunan ekonomi dunia. Dengan demikian maka ekonomi Indonesia akan ikut terkena imbasnya. Bila terjadi penurunan ekonomi maka sektor keuangan dalam hal ini diwakili oleh sektor perbankan yang akan terlebih dahulu turun nilainya.

Analisa yang digunakan menggunakan metode analisa laporan keuangan. Berdasarkan data dari Laporan Keuangan auditan akan dapat dianalisa pertumbuhan sektor perbankan dan kinerja operasional.

Hasil yang ditemukan adalah adanya keterkaitan Return Saham dan ROE Du Pont. ROE yang tinggi akan mengakibatkan naiknya harga saham di pasar. Meskipun demikian apreasiasi pasar terhadap masing-masing bank tidaklah sama karena terdapat bank-bank yang lebih diapresiasi pasar atau sebaliknya terdapat bank-bank yang tidak diapreasiasi setinggi bank lainnya.
\end{abstract}

Keywords: Du Pont ROE, Subprime Mortgage, Analisa Laporan Keuangan, Sentimen Pasar

\section{A. Pendahuluan}

Krisis Sub Prime Mortgage di Amerika berdampak luas pada dunia. Amerika Serikat merupakan salah satu negara dengan ekonomi terbesar. Amerika menjadi pasar yang besar dan juga produsen dunia. Guncangan pada ekonomi Amerika akan berdampak pada seluruh dunia. 
Untuk pergi dari Jakarta dan mendarat di bandara udara JFK New York diperlukan waktu 24 jam. Namun untuk memindahkan dana dari Indonesia ke tempat lain dapat dilakukan secara seketika (real time). Ini merupakan globalisi ekonomi. Sama seperti udara yang akan mengalir dari tempat dingin ke tempat panas. Aliran uang juga akan mengarah dari tempat yang memberikan tingkat pengembalian rendah ke tempat yang memberikan pengembalian yang lebih tinggi.

Indonesia adalah ekonomi yang berdasarkan atas sistem perbankan (bank-based economy). Namun demikian bank-bank terbesar di Indonesia mencari sumber pendaanaan dari pasar modal. Bank-bank terbesar ini dikategorikan oleh Bank Indonesia menjadi empat. Bank Indonesia menyebutnya sebagai Bank Umum berdasarkan Kegiatan Usaha atau yang sering disingkat BUKU. Bank dikelompokkan berdasarkan total aset yang dikelolanya. Bank berukuruan terbesar di Indonesia bila memiliki dana kelolaan di atas 30 trilyun rupiah. Saat ini terdapat lima bank yang memenuhi kriteria ini. Bank-bank tersebut terdiri dari tiga bank milik negara dan dua bank milik swasta. Bank milik Pemerintah terdiri dari Bank Mandiri, Bank Rakyat Indonesia dan Bank Negara Indonesia. Bank milik swasta terdiri dari Bank Central Asia dan CIMB Niaga.

Kelima bank tersebut mencari dana melalui pasar modal. Sama seperti dalam pengkategorian oleh Bank Indonesia, di pasar modal kelima bank tersebut juga menjadi bank-bank dengan nilai kapitalisasi terbesar.Dengan demikian bank-bank ini juga menjadi kapitalisasi utama pasar modal di kategori industri perbankan.

\section{B. Tinjauan Teoritis}

\section{Valuasi Perbankan dan Rasio Du Pont}

Damodaran membagi aset yang dimiliki perusahaan menjadi dua bagian yaitu aset diperlukan untuk beroperasi (asset in place) dan aset yang bertumbuh (growth assets). Aset yang bertumbuh ini akan menghasilkan arus kas di masa depan. Nilai suatu perusahaan diperoleh dengan menilai kinikan total arus kas di masa depan. Pendekatan ini adalah pendekatan fundamental.

Pendekatan fundamental merupakan pendekatan yang kompleks. Kompleks dalam arti diperlukan berbagai input dan asumsi untuk dapat menghasilkan peramalan arus kas masa depan suatu perusahaan. Tingkat kompleksitas suatu penilaian bukan berarti penilaian tersebut menjadi lebih 
tepat. Penilaian akan menjadi lebih tepat apabila asumsi di dalamnya terjadi sesuai dengan kenyataan.

Pendekatan lain yang sederhana namun dapat menunjukkan kinerja perusahaan adalah Return On Equity (ROE). ROE merupakan perbandingan dari Laba Bersih perusahaan dengan Ekuitas yang dimiliki oleh investor.

$\mathrm{ROE}=\frac{\text { Net Income }}{\text { Equity }}$

Formula di atas memiliki keunggulan yaitu dapat dengan cepat dicari dan menunjukkan tingkat profitabilitas perusahaan. Dari formula tersebut terdapat dua informasi penting yang diperoleh yaitu kondisi Laba Bersih dan Ekuitas. Laba bersih dipengaruhi dari berbagai faktor. Faktorfaktor tersebut antara lain adalah

- Pengaruh pajak

- Pengaruh operasional perusahaan

- Efektifitas penggunaan aset dan,

- Pengaruh penggunaan utang

Masing-masing dari faktor tersebut dapat dinilai berdasarkan indikatornya.

- Pengaruh pajak dengan indikator EBIT (1-t)

- Pengaruh operasional perusahaan dengan indikator EBIT

- Efektifitas penggunaan aset dengan indikator Penjualan dibandingkan dengan Aset

- Pengaruh penggunaan utang dengan indikator Aset dibandingkan dengan Ekuitas

Pengaruh Pajak

Tingkat pajak akan memberikan beban kepada bank. Indikator ini menilai bagaimana pengelolaan pajak pada sebuah institusi perbankan. Perbankan

Pengaruh Operasional Perbankan 
Operasional Perbankan terbagi dari dua bagian. Yang pertama adalah bagaimana operasional aktifititas perbankan itu sendiri dan aktifitas untuk mendapatkan dana pihak ketiga. Operasional perbankan yang makin efisiend dengan penggunaan teknologi akan meningkatkan laba operasi perusahaan.

\section{Efektifitas Penggunaan Aset}

Semakin besar suatu bank semakin besar kredit yang dapat disalurkan. Ini berarti bank juga dapat mengambil proyek yang lebih bernilai tinggi dan memerlukan dana besar. Semakin besar aset suatu bank, bank tersebut dapat memberi akses kredit kepada masyarakat yang lebih luas.

Pengaruh Penggunaan Utang

Penggunaan utang dibatasi berdasarkan rasio kecukupan modal. Rasio ini ditetapkan oleh Bank Indonesia agar bank menjaga prinsip kehati-hatian.

\section{Hubungan Antara Keempat Indikator dengan ROE Du Pont}

Keempat faktor tersebut saling terhubung dan bila dihubungkan satu dan lainnya akan membentuk indikator profitabilitas Return on Equity. Penjabaran ini merupakan karya dari seorang analis dari perusahaan Du Pont, karena itu indikator ini sering disebut juga sebagai persamaan Du Pont. Maka bila saling dihubungkan hasilnya akan terlihat seperti di bawah ini:

\begin{tabular}{|c|c|c|c|c|c|}
\hline $\mathrm{ROE}=\underline{\text { Net Income }} \mathrm{x}$ & $\underline{\operatorname{EBIT}(1-t)}$ & $\mathrm{x} \underline{\mathrm{EBIT}}$ & $\underline{\text { Sales }}$ & $\mathrm{X}$ & $\underline{\text { Asset }}$ \\
\hline $\operatorname{EBIT}(1-\mathrm{t})$ & EBIT & Sales & Asset & & Equity \\
\hline
\end{tabular}

ROE dikritik memiliki kelemahan yaitu menggunakan nilai buku dari Ekuitas. Namun di industri seperti perbankan hal ini tidak menjadi masalah karena bank memiliki aset dalam rasio modal minimal. Hal ini dapat terjadi pada industri perbankan karena perbankan adalah industri yang diatur dengan ketat (highly regulated industries). Bank Indonesia sebagai regulator perbankan di Indonesia memberikan peraturan modal minimal yang harus dipatuhi oleh bank. Bila bank melanggar aturan ini maka Bank indonesia dan Otoritas Jasa Keuangan memiliki kekuatan untuk memaksa (enforcing the regulation). Karena itu analisa Du Pont masih tetap dapat digunakan sebagai indikator pada industri perbankan. 


\section{Metode Penelitian}

Penelitian ini menggunakan analisa deskriptif dengan menggunakan metode analisa laporan keuangan. Data yang digunakan adalah data kenaikan harga saham dari seluruh bank BUKU 4 di Indonesia yang kesemuanya terdaftar di Bursa Efek Indonesia. Bank-bank yang dimaksud adalah bank Mandiri, BRI, BCA, BNI 46 dan CIMB Niaga. Selanjutnya data harga saham dari kelima bank tersebut akan dianalisa menggunakan grafik secara urut waktu sehingga terlihat perkembangan dari return saham mulai tahun 2008 hingga tahun 2018.

Untuk menganalisa Return On Equity berdasar formula Du Pont maka diambil dari data laporan keuangan auditan perusahaan tahun 2008 dan tahun 2017. Data ini kemudian dimasukkan ke dalam rasio Du Pont dan dibandingkan pertumbuhannya selama periode setelah krisis Subprime Mortgage tahun 2008 hingga tahun 2018.

Analisa lain yang dilakukan adalah analisa laporan keuangan dengan menggunakan metode analisis Common Size. Metode ini digunakan untuk melihat perbandingan antara akun di dalam laporan keuangan.

\section{Hasil Penelitian dan Pembahasan}

\section{Perkembangan Harga Saham Bank mulai tahun 2008 hingga tahun 2018}

\section{BMRI.JK}

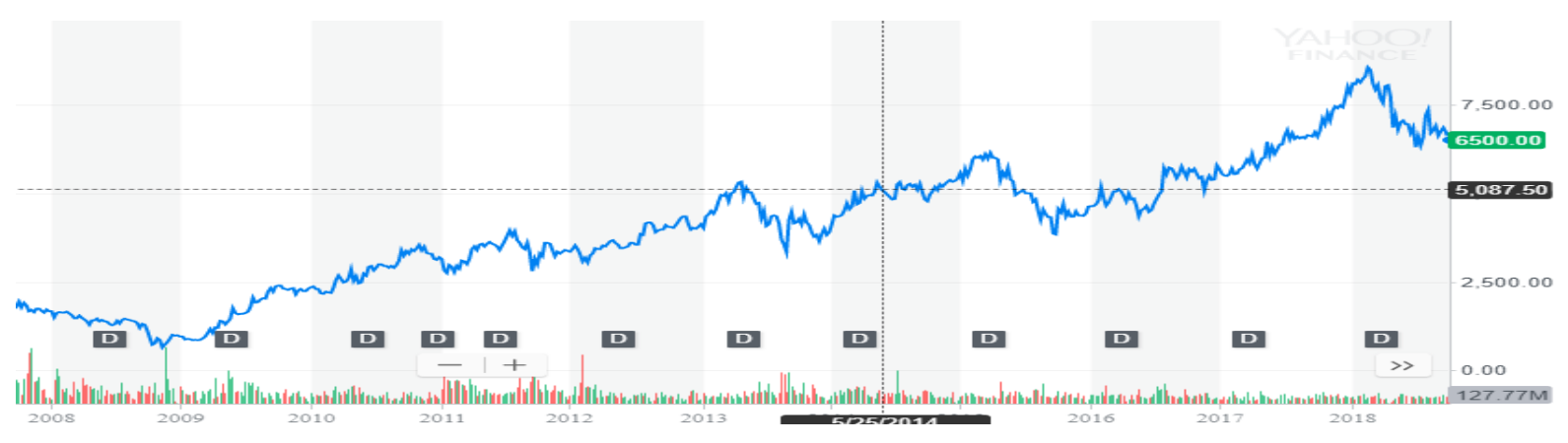

Bank Mandiri adalah sebuah Bank milik negara yang memiliki dana pihak ketiga terbesar saat ini. Bank Mandiri sendiri merupakan hasil dari gabungan empat bank pemerintah yang mengalami masalah likuiditas pada tahun 1998. Sesuai dengan grafik Bank Mandiri mengalami 
kenaikan dari Rp 1.671 pada tanggal 6 Januari 2008 menjadi Rp 8.100 pada tanggal 7 Januari 2018. Ini berarti terjadi kenaikan sebesar $484,74 \%$.

\section{BBCA.JK}

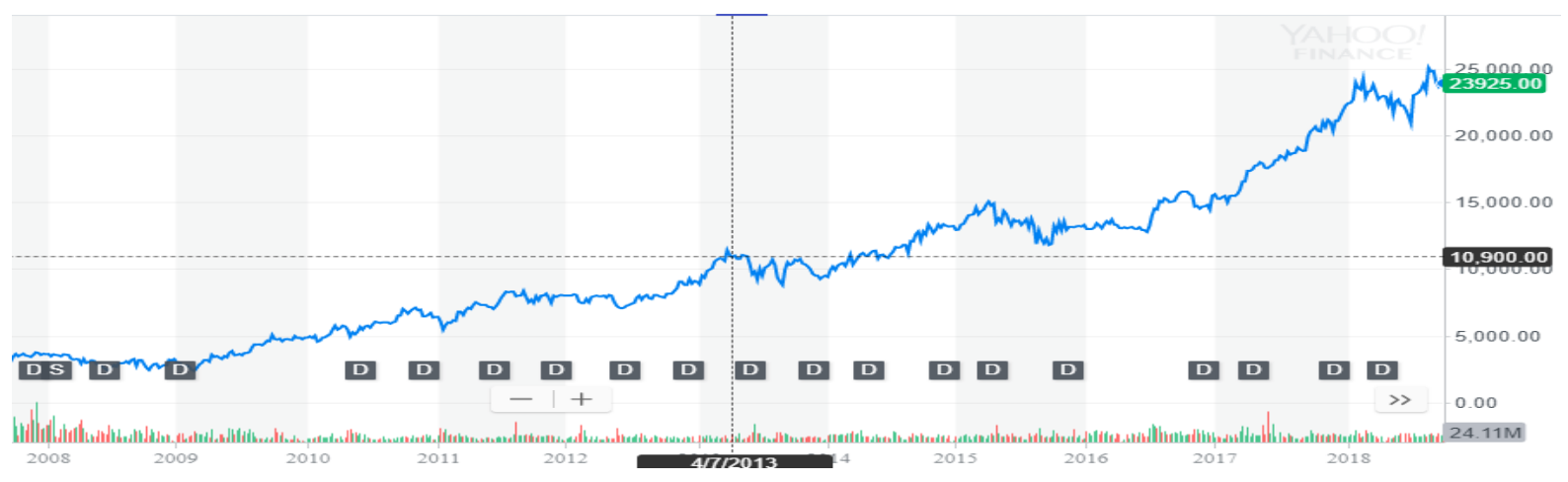

Bank Central Asia merupakan bank swasta terbesar di Indonesia. Bank ini terutama kuat di daerah perkotaan. BCA berusaha memposisikan dirinya dengan keunggulan sistem teknologi informasi. Sesuai dengan grafik Bank BCA mengalami kenaikan dari Rp 15.725 pada tanggal 6 Januari 2018 menjadi Rp 23.875 pada tanggal 7 Januari 2018. Ini berarti kenaikan sebesar $151,83 \%$.

\section{BBNI.JK}

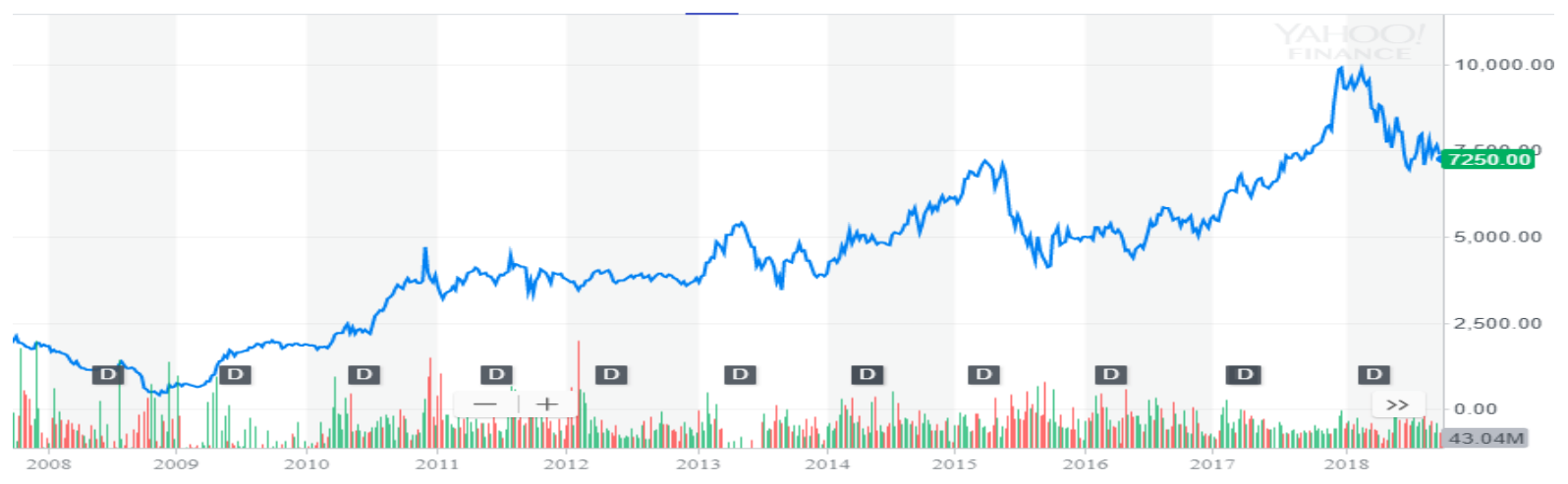

Bank BNI 46 adalah sebuah Bank Umum milik pemerintah yang berdiri sejak awal kemerdekaan dan merupakan hasil nasionalisasi dari bank milik Belanda yang beroperasi di Indonesia. Bank BNI merupakan bersaing pada segmen yang sama dengan bank Mandiri. Sesuai dengan grafik maka Bank BNI 46 mengalami kenaikan dari Rp 1.829 pada tanggal 6 Januari 2008 menjadi Rp 9.275 pada tanggal 7 Januari 2018. Ini berarti kenaikan sebesar 507,11\%. 


\section{BBRI.JK}

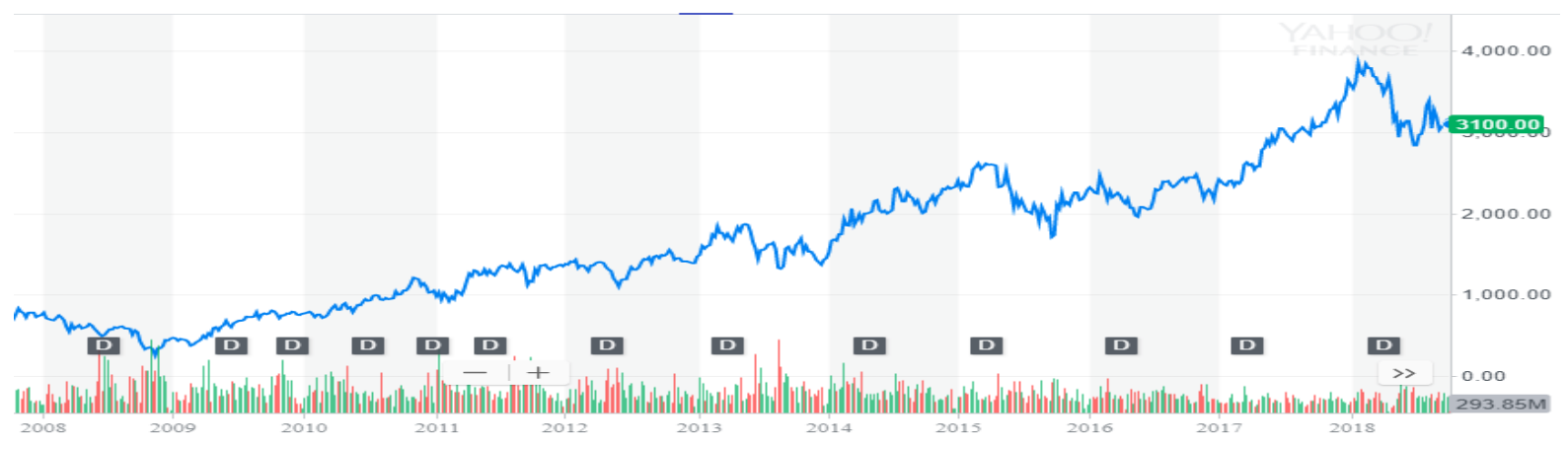

Bank BRI adalah Bank Umum yang semula dibentuk untuk membantu para petani dan pegawai pemerintah di era kolonial untuk mendapatkan bantuan pinjaman guna menghindari jeratan lintah darat. Bank BRI memiliki basis yang kuat hingga ke pedesaan. Karena hal itu banyak kreditkredit dari pemerintah terutama untuk bantuan kepada pengusaha kecil dan mikro disalurkan melalui bank ini. Sesuai dengan grafik maka Bank BRI mengalami kenaikan dari Rp 780 pada tanggal 6 Januari 2008 menjadi Rp 3.540 pada tanggal 7 Januari 2018. Ini berarti kenaikan sebesar $453,85 \%$.

\section{BNGA.JK}

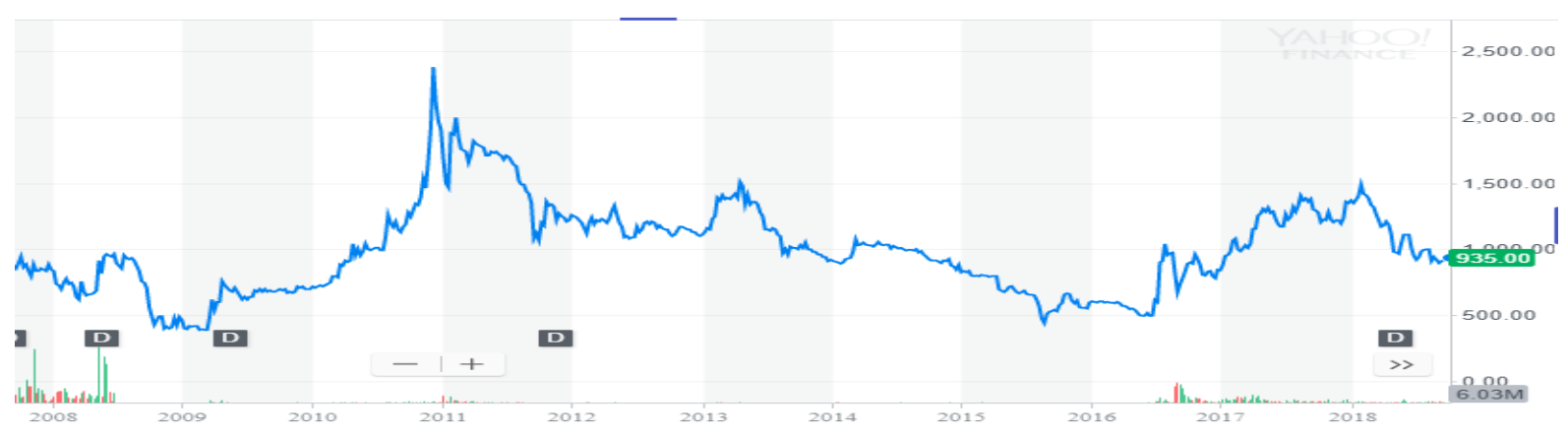

Bank Niaga adalah satu-satunya bank swasta selain Bank BCA yang bisa memasuki daftar bankbank terbesar di Indonesia. Bank Niaga pada awalnya adalah bank Swasta milik Indonesia secara penuh namun kemudian dibeli mayoritas sahamnya oleh Bank CIMB Bhd dari Malaysia. Dengan tambahan modal tersebut kini bank Niaga dapat mengelola dana hingga di atas 30 trilyun rupiah. 
Bank Niaga mengalami kenaikan dari Rp 834 pada tanggal 6 Januari 2008 menjadi Rp 1.350 pada tanggal 7 Januari 2018. Ini berarti kenaikan sebesar 161,87\%.

Analisa Common Size terhadap Laba dan Penjualan pada tahun 2008

\begin{tabular}{|l|r|r|r|r|r|}
\hline & BBRI & BBCA & BMRI & BBNI & BNGA \\
\hline Net Income & $21 \%$ & $47 \%$ & $35 \%$ & $7 \%$ & $7 \%$ \\
EBIT(1-t) & $49 \%$ & $62 \%$ & $101 \%$ & $12 \%$ & $7 \%$ \\
EBIT & $63 \%$ & $62 \%$ & $130 \%$ & $11 \%$ & $13 \%$ \\
Sales & $100 \%$ & $100 \%$ & $100 \%$ & $100 \%$ & $100 \%$ \\
\hline
\end{tabular}

Analisa Common Size terhadap Laba dan Penjualan pada tahun 2018

\begin{tabular}{|l|r|r|r|r|r|}
\hline & BBRI & BBCA & BMRI & BBNI & BNGA \\
\hline Net Income & $21 \%$ & $43 \%$ & $41 \%$ & $29 \%$ & $24 \%$ \\
EBIT(1-t) & $28 \%$ & $54 \%$ & $52 \%$ & $36 \%$ & $416 \%$ \\
EBT & $36 \%$ & $106 \%$ & $52 \%$ & $36 \%$ & $411 \%$ \\
Sales & $100 \%$ & $100 \%$ & $100 \%$ & $100 \%$ & $1240 \%$ \\
\hline
\end{tabular}

Perhitungan Formula Du Pont untuk Kelima Bank pada tahun 2008

\begin{tabular}{|l|l|l|l|l|l|}
\hline & BBRI & BBCA & BMRI & BBNI & BNGA \\
\hline Net Income & 5,96 & 5,78 & 5,31 & 1,22 & 0,68 \\
EBIT(1-t) & 13,81 & 7,72 & 15,51 & 1,93 & 0,68 \\
EBIT & 17,70 & 7,67 & 19,89 & 1,87 & 1,32 \\
Sales & 28,10 & 12,36 & 15,29 & 16,62 & 10,05 \\
Assets & 246,07 & 245,57 & 358,44 & 201,74 & 103,20 \\
Equity & 22,36 & 23,28 & 30,51 & 15,43 & 9,30 \\
ROE & $27 \%$ & $25 \%$ & $17 \%$ & $8 \%$ & $7 \%$ \\
\hline
\end{tabular}

Perhitungan Formula Du Pont untuk Kelima Bank pada tahun 2018

\begin{tabular}{|l|l|l|l|l|l|}
\hline & BBRI & BBCA & BMRI & BBNI & BNGA \\
\hline Net Income & 21,35 & 23,32 & 21,44 & 13,77 & 2,98 \\
EBIT(1-t) & 28,88 & 29,16 & 27,17 & 17,22 & 4,16 \\
EBIT & 37,02 & 56,98 & 27,16 & 17,17 & 4,11 \\
Sales & 102,90 & 53,77 & 52,33 & 48,18 & 12,40
\end{tabular}




\begin{tabular}{|l|l|l|l|l|l|} 
Assets & 1126,25 & 750,32 & $1.124,70$ & 709,33 & 266,31 \\
Equity & 167,35 & 131,40 & 170 & 100,90 & 36,95 \\
ROE & $13 \%$ & $18 \%$ & $13 \%$ & $14 \%$ & $8 \%$ \\
\hline
\end{tabular}

Pertumbuhan dari tahun 2008 ke tahun 2018

\begin{tabular}{|l|l|l|l|l|l|}
\hline & BBRI & BBCA & BMRI & BBNI & BNGA \\
\hline Net Income & $358 \%$ & $404 \%$ & $404 \%$ & $1126 \%$ & $439 \%$ \\
EBIT(1-t) & $209 \%$ & $378 \%$ & $175 \%$ & $891 \%$ & $608 \%$ \\
EBIT & $209 \%$ & $743 \%$ & $137 \%$ & $916 \%$ & $310 \%$ \\
Sales & $366 \%$ & $435 \%$ & $342 \%$ & $290 \%$ & $123 \%$ \\
Assets & $458 \%$ & $306 \%$ & $314 \%$ & $352 \%$ & $258 \%$ \\
Equity & $748 \%$ & $564 \%$ & $557 \%$ & $654 \%$ & $397 \%$ \\
ROE & $48 \%$ & $72 \%$ & $72 \%$ & $172 \%$ & $111 \%$ \\
\hline
\end{tabular}

Perbandingan pertumbuhan ROE dan pertumbuhan Price Return Saham

\begin{tabular}{|l|l|l|l|l|l|}
\hline & BBRI & BBCA & BMRI & BBNI & BNGA \\
\hline ROE & $48 \%$ & $72 \%$ & $72 \%$ & $172 \%$ & $111 \%$ \\
\hline Return & $454 \%$ & $152 \%$ & $485 \%$ & $507 \%$ & $162 \%$ \\
\hline
\end{tabular}

\section{Analisa Pertumbuhan}

Dari data di atas ada beberapa hal yang dapat disimpulkan. Kelima aset semua bank tumbuh lebih dari dua kali lipat selama periode setelah krisis. Bank BRI memiliki pertumbuhan yang paling rendah yaitu sebanyak dua kali sedangkan bank BNI 46 memiliki pertumbuhan aset kelolaan hingga hampir empat kali lipat.

Pertumbuhan penjualan paling tinggi dialami oleh BCA dan bank Niaga memiliki penjualan paling rendah. Namun dilihat dilihat dari Net Income perusahaan yang Bank BNI yang memiliki pertumbuhan Net Income terbesar.

\section{Analisa Common Size}

Dari analisa common size dapat diketahui asal dari pertumbuhan Net Income bank BNI dan Bank Niaga. Kedua bank ini memiliki pertumbuhan Net Income karena terdapat perbaikan pada kinerja operasional. Bank Niaga baru saja melakukan merger dengan CIMB pada tahun 2008. Pada saat itu bank BUKU 4 hanya terdapat empat bank yaitu Bank BRI, Mandiri, BCA dan BNI. 
Dari tabel Common Size 2008 terlihat bahwa Net Income BNI dan Niaga berada di angka 7\%. Pada tahun yang sama Bank BCA memimpin dengan Net Income sebesar 47\%, Bank Mandiri dengan 38\% dan Bank BRI dengan 21\%. Ini berarti dibandingkan dengan bank-bank tersebut bank BNI 46 dan Niaga secara relatif tidak efisien karena biaya operasionalnya memakan hampir keseluruhan laba.

Dari tabel Common Size 2018 terlihat bahwa Net Income BNI dan Niaga berada di 29\% dan 24\%. Angka ini lebih tinggi dari Net Income BRI yang berada pada 21\%. Walaupun demikian kinerja BNI 46 dan Bank Niaga masih kalah dibandingkan dengan Bank Mandiri dan BCA yang berada pada angka $43 \%$ dan $41 \%$.

\section{Sentimen Pasar}

Bila dilihat reaksi pasar, maka pasar bersikap konsisten terhadap BNI. Pasar mengapresiasi tingginya ROE BNI dengan memberikan return pasar yang tinggi. Namun hal ini tidak sesuai dengan kondisi Bank Mandiri dan Bank BCA dan Bank BRI. Dari grafik harga historis terlihat bahwa ketiga bank ini memiliki likuiditas yang tinggi di pasar. Tetapi pasar lebih mengapreasiasi bank Mandiri dan bank BRI daripada bank BCA. Bila bank BCA dikecualikan maka hubungan antara return saham dan ROE maka akan berkorelasi positif.

Di sisi yang lain pasar tetap mengapresiasi Bank Mandiri dan Bank BCA yang menjaga kinerja operasional kedua perusahaan ini. Hanya saja dalam hal ini apresiasi pasar yang diberikan terhadap BCA tidak setinggi terhadap ketiga Bank BUMN yang menjadi kompetitornya.

\section{E. Simpulan dan Saran}

\section{Simpulan}

ROE dan tingkat pengembalian memiliki korelasi positif. Artinya semakin tinggi ROE semakin tinggi tingkat pengembalian saham bagi investor. Hal ini konsisten dengan hasil penelitianpenelitian sebelumnya. Yang menjadi temuan dari penelitian ini adalah likuiditas berperan penting bagi return saham. Bank BRI dan Bank Mandiri merupakan market darling yang dengan aktif diperdagangkan. Sedangkan untuk Bank BNI, apreasiasi pasar yang terlihat dari tingkat return saham yang tinggi dikarenakan karena Bank BNI dan Bank Niaga bisa meningkatkan kinerja operasionalnya. 
Dilihat dari periode penelitian ini tidak terlihat pengaruh likuiditas terhadap pertumbuhan bankbank BUKU 4. Bank BNI dan Niaga tetap bisa memperbaiki kinerja operasionalnya dan mendapatkan apresiasi dari pasar. Sementara itu Bank BRI, Mandiri dan BCA tetap dapat mempertahankan kinerja operasionalnya dan return sahamnya terus bertumbuh selama periode 2008 hingga 2018.

Dari penelitian ini tidak terlihat hubungan antara hubungan krisis Subprime Mortgage tahun 2008 dengan pertumbuhan bank-bank BUKU 4 di Indonesia. Walaupun demikian masih diperlukan penyelidikan lebih lanjut mengenai hal ini.

\section{Saran untuk Penelitian Selanjutnya}

Pada penelitian ini yang dilihat hanyalah data dari return saham dan kinerja bank yang dilihat dari laporan keuangan. Belum dilihat hubungan antara faktor-faktor pada penelitian ini dengan indikator makro dalam negeri atau korelasinya dengan kondisi makro negara yang memiliki keterkaitan dengan pasar modal Indonesia.

\section{Daftar Referensi :}

\section{Jurnal:}

Vanniarajan T and Samuel Joseph.C (2007) An Application of DuPont control chart in analyzing the financial performance of banks, the management accountant, pp-614-617.

Prendergast, P. Financial analysis: how a "modified DuPont approach" to ratio analysis can be used to drill down to the true cause of financial performance problems, Financial Management, Paper P8, May, 2006, pp. 48-49.

Beaver, Kennelly \& Voss (1968), Predictive ability as a criterion for the evaluation of accounting data, Accounting Review, October, pp. 675-83.

Fraser, Donald R., Benton E. Gup, and James W. Kolari (2001), Commercial Banking, Second Edition, South-Western College Publishing, Cincinnati, pp. 60-65. 